\title{
High-Yield Synthesis of Zinc Oxide Nanoparticles from Bicontinuous Microemulsions
}

\author{
S. López-Cuenca, ${ }^{1}$ L. A. Pérez Carrillo, ${ }^{1}$ M. Rabelero Velasco, ${ }^{1}$ R. Díaz de León, ${ }^{2}$ H. Saade, ${ }^{2}$ \\ R. G. López, ${ }^{2}$ E. Mendizábal, ${ }^{1}$ and J. E. Puig ${ }^{1}$ \\ ${ }^{1}$ Departamentos de Ingeniería Química y Química, CUCEI, Universidad de Guadalajara, Boul. M. García Barragán No. 1431, \\ 44430 Guadalajara, JAL, Mexico \\ ${ }^{2}$ Departamento de Procesos de Polimerización, Centro de Investigación en Química Aplicada, Boulevard Enrique Reyna No. 140, \\ 25253 Saltillo COAH, Mexico \\ Correspondence should be addressed to R. G. López, glopez@ciqa.mx
}

Received 26 April 2011; Accepted 19 August 2011

Academic Editor: Takuya Tsuzuki

Copyright () 2011 S. López-Cuenca et al. This is an open access article distributed under the Creative Commons Attribution License, which permits unrestricted use, distribution, and reproduction in any medium, provided the original work is properly cited.

The high-yield synthesis of zinc oxide $(\mathrm{ZnO})$ primary nanoparticles with high purity and with diameters between 6 and $22 \mathrm{~nm}$ using bicontinuous microemulsions is reported in this work. The $\mathrm{ZnO}$ nanoparticles were made by hydrolysis of $\mathrm{Zn}\left(\mathrm{NO}_{3}\right)_{2}$ with $\mathrm{NaOH}$ aqueous solution and precipitation, followed by calcination of the precipitate. Higher yields and productivities of $\mathrm{ZnO}$ nanoparticles were obtained compared to values produced with w/o micremulsions reported in the literature. Particles were characterized by transmission electronic microscopy (TEM), X-ray diffraction, and atomic absorption spectroscopy.

\section{Introduction}

$\mathrm{ZnO}$ is attracting considerable attention because its wide band energy gap $(3.37 \mathrm{eV})$ and its high exciting emission efficiency, which makes it suitable for UV emission devices [1]. Because quantum confined effects in nanostructural dimensions, improved $\mathrm{ZnO}$-based UV emission devices can be produced. Other potential applications of $\mathrm{ZnO}$ nanomaterials include optoelectronics, nanolasers, solar cells, gas sensors, antibacterial, and health-related applications [28].

Different techniques for preparing $\mathrm{ZnO}$ nanoparticles have been investigated such as sol-gel process $[9,10]$, chemical coprecipitation $[11,12]$, chemical vapor deposition [13], thermal decomposition [14, 15], hydrothermal synthesis [16], solid-state reaction [17], spray pyrolysis [18], and microemulsion precipitation [19-23]. These techniques have allowed obtaining various $\mathrm{ZnO}$ structures such as nanospheres, nanorods, nanowires, nanotubes, and flowerlike nanostructures. Among these, precipitation in reverse microemulsions is a well-established technique for preparing particles with average diameters smaller than $10 \mathrm{~nm}$ and low particle size polydispersity [24-26]. However, the preparation of $\mathrm{ZnO}$ nanoparticles by this method has been scarcely investigated [19-23]. According to these reports, $\mathrm{ZnO}$ nanoparticles with average diameters around $10 \mathrm{~nm}$ [19-21, 23] up to ca. $\cong 150 \mathrm{~nm}$ [22] have been obtained. Hingorani et al. reported the first synthesis of $\mathrm{ZnO}$ nanoparticles via reverse microemulsions in the early 1990s [19, 20]. These authors mixed two reverse microemulsions, one containing a zinc nitrate aqueous solution and the other an ammonium carbonate aqueous solution, to obtain zinc carbonate nanoparticles; further calcination of this compound leaded to spherical nanoparticles of $\mathrm{ZnO}$ with $14 \mathrm{~nm}$ in average diameter [19]. Later, the same group used reverse microemulsions stabilized with zinc (bis ethylhexyl)sulfosuccinate to precipitate zinc oxalate by adding oxalic acid. $\mathrm{ZnO}$ nanoparticles of about $5-13 \mathrm{~nm}$ in diameter were obtained by zinc oxalate calcination [21]. Lim et al. reported the preparation of $\mathrm{ZnO}$ particles via bicontinuous microemulsions [22]. A solution of sodium hydroxide was added to a microemulsion containing a zinc nitrate aqueous solution to precipitate zinc hydroxide, which was then calcined to obtain spherical-shaped $\mathrm{ZnO}$ particles. However, 
these particles were very large (ca. $150 \mathrm{~nm}$ in diameter). This unusually large particle size obtained via microemulsion precipitation was ascribed by the authors to grain growth and particle agglomeration during the calcination process. More recently, Inoguchi et al. [23] reported the preparation of spherical $\mathrm{ZnO}$ nanoparticles as small as $5 \mathrm{~nm}$ in average diameter by direct precipitation in a reverse microemulsion containing an aqueous solution of sodium hydroxide to which an alcoholic solution of zinc diethoxide was added.

In reverse microemulsion precipitation, the hydrolysis reactions take place inside the water-microemulsion droplets suspended in a hydrophobic medium; however, this technique has the drawback that the productivity of nanoparticles is low. Some authors have employed bicontinuous microemulsions rather than w/o microemulsions because the ratio of water-to-oil is larger, which increases the productivity of metal oxide nanoparticles, keeping the typical size of nanoparticles obtained in reverse microemulsions [22, 2729].

In this work, we report the synthesis of $\mathrm{ZnO}$ nanoparticles employing bicontinuous microemulsions. This method allows obtaining higher yields and productivities because bicontinuous microemulsions contain larger aqueous phase concentrations, where the $\mathrm{ZnO}$ precursor is located, than w/o microemulsions. Particles were characterized by transmission electronic microscopy (TEM), X-ray diffraction, and atomic absorption spectroscopy.

\section{Materials and Methods}

2.1. Materials. Sodium dodecyl sulfate (SDS), sodium bis2-ethylhexyl sulfosuccinate (AOT), and $\mathrm{Zn}\left(\mathrm{NO}_{3}\right) \cdot 6 \mathrm{H}_{2} \mathrm{O}$ were all 98\% pure from Sigma-Aldrich. $\mathrm{NaOH}, 98.2 \%$ pure (Golden Bell), and toluene, 99\% pure (Golden Bell), were used as received. De-ionized and triple-distilled water with conductivity smaller than $6 \mu \mathrm{S} / \mathrm{cm}$ was used.

\subsection{Phase Diagram and Electrical Conductivity Determina-} tions. The one-phase microemulsion region at the reaction temperature $\left(70^{\circ} \mathrm{C}\right)$ was determined by titrating solutions of AOT/SDS (2/1 by weight) in toluene at different surfactant concentrations (in the range of 5 to 70 surfactant wt.\%) with $0.9 \mathrm{M} \mathrm{Zn}\left(\mathrm{NO}_{3}\right)_{2}$ aqueous solution under continuous agitation. The phase boundaries were detected as those compositions where samples became turbid. Samples were also examined with cross-polarizers to rule out liquid crystalline phases that might form. Phase boundaries were determined more accurately by weighing the components and by observing the samples in the neighborhood of the titration-determined compositions.

To determine the mixture compositions where bicontinuous microemulsion formed, conductivities of samples along lines A, B, and C in Figure 1 were determined with a 3173 R JENCO conductivity meter at $70^{\circ} \mathrm{C}$.

2.3. Bicontinuous Microemulsion Precipitation. The hydrolysis of $\mathrm{Zn}\left(\mathrm{NO}_{3}\right)_{2}$ and precipitation of the nanoparticles were carried out by duplicate at $70^{\circ} \mathrm{C}$ by dosing an $\mathrm{NaOH}$ aqueous solution at different feeding rates to give total feeding times of 100,125 , and $150 \mathrm{~min}$. The total added amount of $\mathrm{NaOH}$ was 1.43 times the stoichiometric ratio $\left(\mathrm{NaOH} / \mathrm{Zn}\left(\mathrm{NO}_{3}\right)_{2}\right)$. After the addition period, the reacting system was left to stand for $30 \mathrm{~min}$ at the reaction temperature. The precipitate was recovered by filtration and mixed with an aqueous acetone solution $(81 / 19 \mathrm{w} / \mathrm{w})$ in a sonic bath for 15 minutes to remove the surfactants and nonreacted material and centrifuged to recover the wet solids. This procedure was repeated 10 times. The residual wet solid was then dried in an oven at $60^{\circ} \mathrm{C}$ and then calcined at $400^{\circ} \mathrm{C}$ for two hours in an oven.

2.4. Nanoparticles Characterization. The resulting product, a fine powder, was characterized in a Siemens D-5000 Xray diffractometer (XRD). Particle size was determined by transmission electronic microscopy (TEM) in a JEOL JEM1010; for this, the resulting powder was dispersed in acetone with an ultrasonicator, and then a drop of the dispersion was deposited on a copper grid, where the solvent was allowed to evaporate. The purity of the final product was determined by atomic absorption spectrometry with a Varian Spectra 250 AA equipment.

\section{Results and Discussion}

3.1. Phase Diagram. Because it is desirable to obtain the largest amount possible of $\mathrm{ZnO}$ nanoparticles during the synthesis, preliminary experiments in bicontinuous microemulsions were carried out using $\mathrm{Zn}\left(\mathrm{NO}_{3}\right)_{2}$ aqueous solutions of different concentration. These experiments revealed that it was possible to use $\mathrm{Zn}\left(\mathrm{NO}_{3}\right)_{2}$ aqueous solutions with concentrations up to $0.9 \mathrm{M}$. Figure 1 shows the microemulsion region for the system containing a mixture of AOT/SDS (2/1 by weight), toluene, and a $0.9 \mathrm{M}$ aqueous solution of $\mathrm{Zn}\left(\mathrm{NO}_{3}\right)_{2}$. Three ratios of the surfactants/toluene mixture, which allowed a high percent of aqueous solution inside the microemulsion region, were selected. To find the bicontinuous microemulsion zone, the content of the $0.9 \mathrm{M}$ aqueous $\mathrm{Zn}\left(\mathrm{NO}_{3}\right)_{2}$ solution was increased while maintaining the ratio of surfactants/toluene constant (lines A, B, and C, in Figure 1) and the conductivity of the different resulting mixtures was measured.

3.2. Electrical Conductivities. Figure 2 depicts the electrical conductivity as a function of the amount of aqueous solution of $\mathrm{Zn}\left(\mathrm{NO}_{3}\right)_{2}$ for the three surfactants/toluene ratios selected $(50 / 50,55 / 45$, and $60 / 40 \mathrm{w} / \mathrm{w})$. In all cases, a bell-shaped curve was obtained. By increasing the aqueous solution content, the microemulsion conductivity increased until a maximum value was reached, followed by a drop in conductivity. According to the percolation theory, bicontinuous microemulsions show a high conductivity as a result of having a continuous (or connected) aqueous phase domains [30-33]. When the ratios of surfactants/toluene were 50/50 and 55/45, the conductivities were very low, which indicated that w/o microemulsions, instead of bicontinuous microemulsions, formed. However, a big increase in 


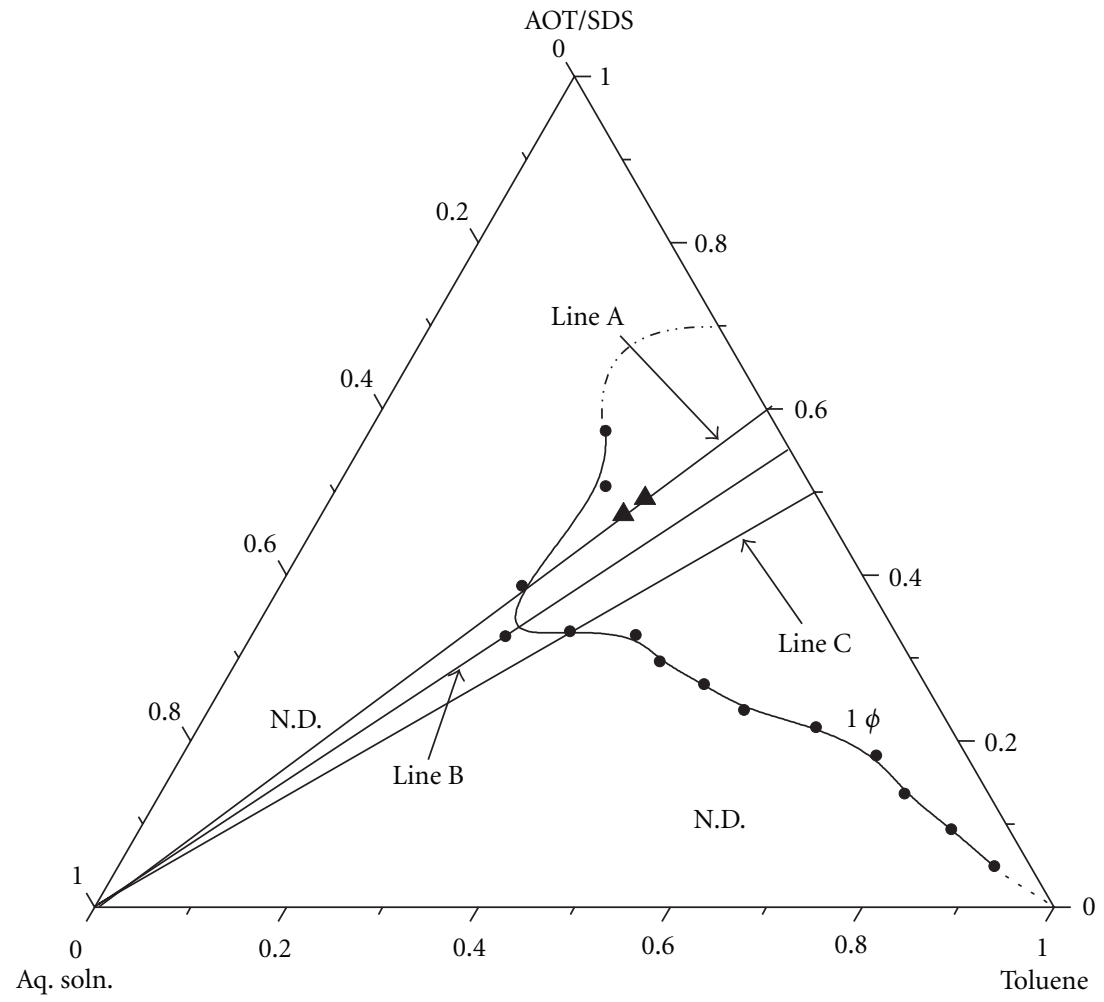

Figure 1: Partial phase diagram obtained at $70^{\circ} \mathrm{C}$ for mixtures of toluene, AOT/SDS $(2 / 1 \mathrm{w} / \mathrm{w})$, and $0.9 \mathrm{M} \mathrm{Zn}\left(\mathrm{NO}_{3}\right)_{2}$ aqueous solution. The one-phase microemulsion region $(1 \phi)$ is located between the surfactants mixture/toluene axis and the solid line; here, lines $\mathrm{A}, \mathrm{B}$, and $\mathrm{C}$ indicate where conductivity measurements were performed to examine the structure of the microemulsions. Solid triangles indicate the compositions where the precipitation reactions were made.

conductivity was detected when the surfactants/toluene ratio of $60 / 40(\mathrm{w} / \mathrm{w})$ with a percent of aqueous solution larger than $15 \%$ was used, reaching a maximum of $1575 \mu \mathrm{S} / \mathrm{cm}$ around $27 \%$ of aqueous solution, indicating bicontinuous structure. Then it decreased to low values, due to the formation of $\mathrm{o} / \mathrm{w}$ microemulsions. Similar behavior was reported with a $0.5 \mathrm{M} \mathrm{Zn}\left(\mathrm{NO}_{3}\right)_{2}$ aqueous solution in a microemulsion containing $57.4 \mathrm{wt} . \%$ petroleum spirit as the oil phase and $24.6 \mathrm{wt} . \%$ poly(oxyethylene) ${ }_{5}$ nonylphenol ether as the nonionic surfactant, that is, a conductivity rise as the amount of aqueous solution was increased up to a maximum $(600 \mu \mathrm{S} / \mathrm{cm})$, followed by a large decrease. This was attributed to the transition from inverse to bicontinuous and then to inverse microemulsions [22]. Transitions from inverse to bicontinuous microemulsions or from bicontinuous to inverse microemulsions are well documented in the literature [30-33].

3.3. Preparation and Characterization of $\mathrm{ZnO}$ Nanoparticles. To obtain the $\mathrm{ZnO}$ nanoparticles, two compositions in the bicontinuous region with high conductivity along the line A (see Figure 1 ) were chosen $(22 \%$ and $27 \%$ of $0.9 \mathrm{M}$ aqueous $\mathrm{Zn}\left(\mathrm{NO}_{3}\right)_{2}$ solution). Table 1 shows the $\mathrm{Zn}\left(\mathrm{NO}_{3}\right)_{2}$ concentrations and the dosing times used in this work. When the $\mathrm{NaOH}$ aqueous solution was added, a precipitate formed.

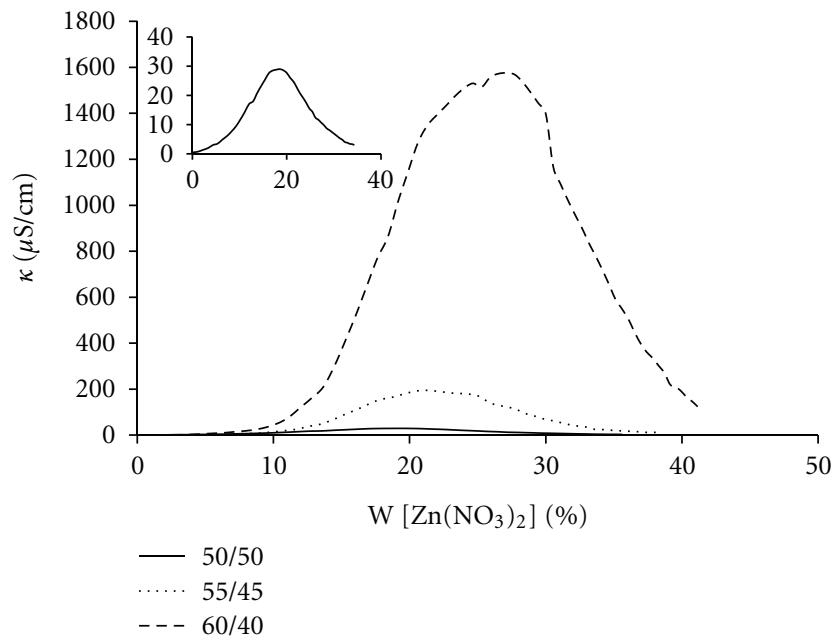

FIGURE 2: Electrical conductivity of the one-phase microemulsions versus concentration of a $0.9 \mathrm{M} \mathrm{Zn}\left(\mathrm{NO}_{3}\right)_{2}$ aqueous solutions for three surfactant mixture/toluene weight ratios. Inset: enlargement of conductivity data for the $50 / 50 \mathrm{w} / \mathrm{w}$ surfactant mixture/toluene ratio.

The X-ray diffraction (XRD) pattern of the precipitate of the 125-2 sample (Figure 3) before calcination shows the characteristic peaks of the $\mathrm{ZnO}$ with a hexagonal wurtzite crystal structure and also small peaks which are attributed 
TABLE 1: ZnO nanoparticles $D_{n}$ and PDI determined by TEM, purity, productivity, and yield of the reaction.

\begin{tabular}{|c|c|c|c|c|c|c|c|}
\hline Sample & $\begin{array}{c}\mathrm{Zn}\left(\mathrm{NO}_{3}\right)_{2} \\
\text { concentration (wt.\%) } \\
\text { in microemulsion }\end{array}$ & $\begin{array}{l}\text { Dosing time } \\
\quad(\min )\end{array}$ & $D_{n}(\mathrm{~nm})$ & PDI & $\begin{array}{c}\mathrm{ZnO}^{\mathrm{a}} \\
\text { purity (\%) }\end{array}$ & $\begin{array}{c}\text { Productivity } \\
\text { (g ZnO/100 g reaction } \\
\text { mixture) }\end{array}$ & Yield $^{\mathrm{b}}(\%)$ \\
\hline $100-1$ & 22 & 100 & $21.74 \pm 4.03$ & 1.10 & 98 & 1.25 & 98.27 \\
\hline $125-1$ & 22 & 125 & $18.40 \pm 4.62$ & 1.17 & 99 & 1.13 & 88.83 \\
\hline $150-1$ & 22 & 150 & $8.74 \pm 2.89$ & 1.38 & 95 & 1.11 & 87.26 \\
\hline $100-2$ & 27 & 100 & $7.81 \pm 1.94$ & 1.19 & 99 & 1.30 & 85.30 \\
\hline $125-2$ & 27 & 125 & $6.00 \pm 1.52$ & 1.21 & 98 & 1.34 & 87.93 \\
\hline $150-2$ & 27 & 125 & $6.50 \pm 1.89$ & 1.3 & 96 & 1.36 & 89.24 \\
\hline
\end{tabular}

${ }^{a}$ Calculated from atomic absorption determinations.

$\mathrm{b}($ Experimental weight of $\mathrm{ZnO} /$ theoretical weight of $\mathrm{ZnO}) \times 100$.

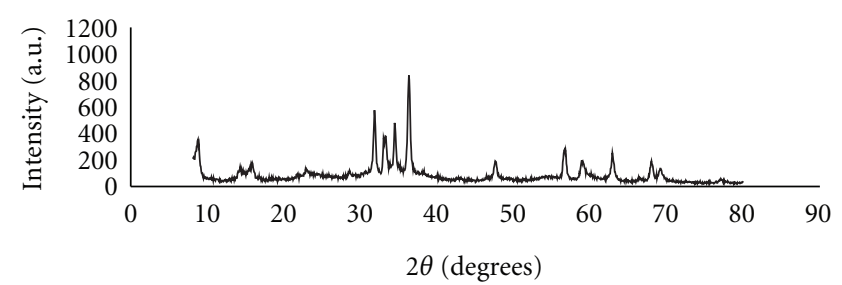

(a)

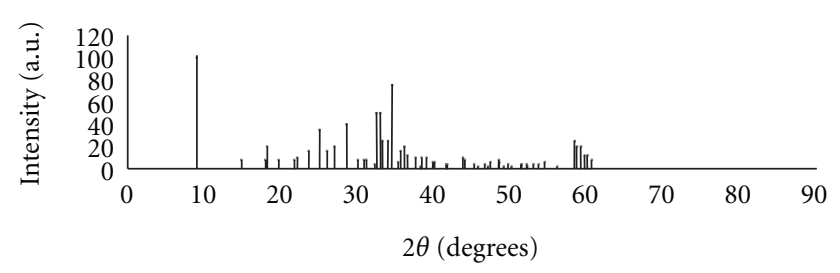

(b)

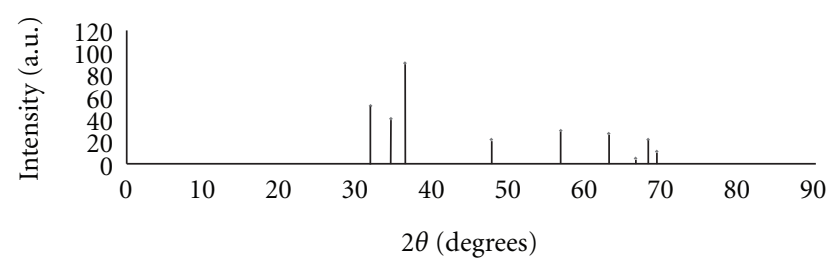

(c)

FIGURE 3: X-ray diffraction pattern of sample 125-2 before calcination (a). For comparison, the standard X-ray diffraction patterns of $\mathrm{Zn}\left(\mathrm{NO}_{3}\right)_{2} \cdot 6 \mathrm{H}_{2} \mathrm{O}$ (b) (JCPDS card 24-1460) and $\mathrm{ZnO}$ (c) [34] were included.

to $\left(\mathrm{Zn}_{5}(\mathrm{OH})_{8}(\mathrm{NO} 3)_{2} \cdot 2 \mathrm{H}_{2} \mathrm{O}\right.$. Similar XRD patterns were obtained for the other precipitates. Gusatti et al. [34] reported the production of $\mathrm{ZnO}$ particles with sizes between 25 and $28.5 \mathrm{~nm}$ with high purity by reacting an aqueous $\mathrm{Zn}\left(\mathrm{NO}_{3}\right)_{2} \cdot 6 \mathrm{H}_{2} \mathrm{O}$ solution with an aqueous $\mathrm{NaOH}$ solution. All the XRD patterns of the calcined samples showed only peaks that correspond to $\mathrm{ZnO}$ with a hexagonal wurtzite crystal structure indicating that $\mathrm{ZnO}$ nanoparticles with high purity were obtained. The XRD pattern of sample 1252 is shown in Figure 4 as an example. Upon calcination, $\left(\mathrm{Zn}_{5}(\mathrm{OH})_{8}(\mathrm{NO} 3)_{2} \cdot 2 \mathrm{H}_{2} \mathrm{O}\right.$ lost water and decomposed to produce $\mathrm{ZnO}$. Atomic absorption analysis (Table 1) indicates

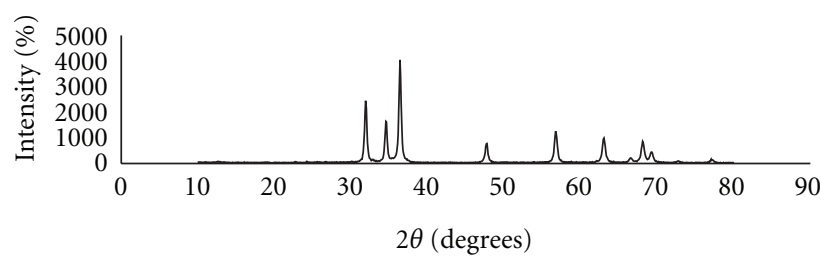

(a)

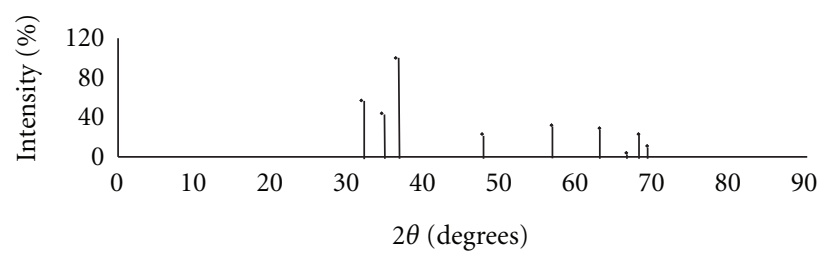

(b)

FIGURE 4: X-ray diffraction pattern of sample 125-2 after calcination (a); the standard X-ray diffraction pattern for $\mathrm{ZnO}$ from the literature [34] was included (b).

that the purity of the nanoparticles is around 98\%, which confirms the results of XRD.

Micrographs of the precipitate before calcination (Figure 5(a)) and of the $\mathrm{ZnO}$ nanoparticles (Figure 5(b)) of the sample 125-2 show that primary particles with diameters between 3 and $9 \mathrm{~nm}$ were obtained. The $\mathrm{ZnO}$ nanoparticles number-average diameter $\left(D_{n}\right)$ and the polydispersity index, PDI $\left(D_{w} / D_{n}\right)$, where $D_{w}$ is the weight-average diameter, were calculated by measuring ca. 540 particles. These results are included in Table 1.

Table 1 discloses that by decreasing the addition rate of the $\mathrm{NaOH}$ solution, smaller particles were obtained, which is more obvious with the sample containing $22 \%$ of aqueous solution of $\mathrm{Zn}\left(\mathrm{NO}_{3}\right)_{2}$. This can be explained by the smaller amount of primary nanoparticles formed at a given time, which causes a lower probability for particle coalescence and agglomeration by interparticle collision. Table 1 also shows that by increasing the content of the $\mathrm{Zn}\left(\mathrm{NO}_{3}\right)_{2}$ aqueous solution, smaller particles were obtained because the water channels become wider, and hence there are less primary particles per unit volume to promote particle growth or agglomeration. 


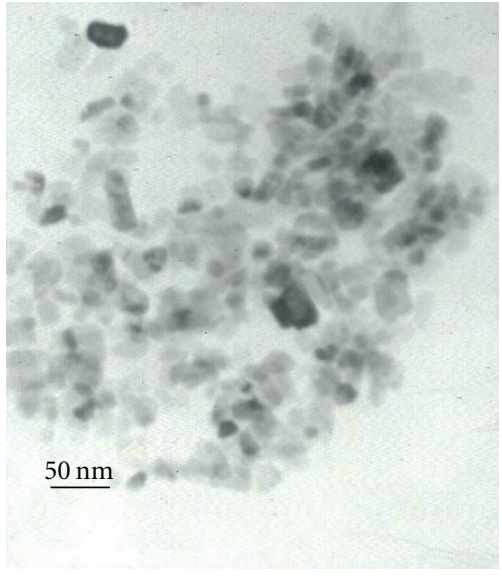

(a)

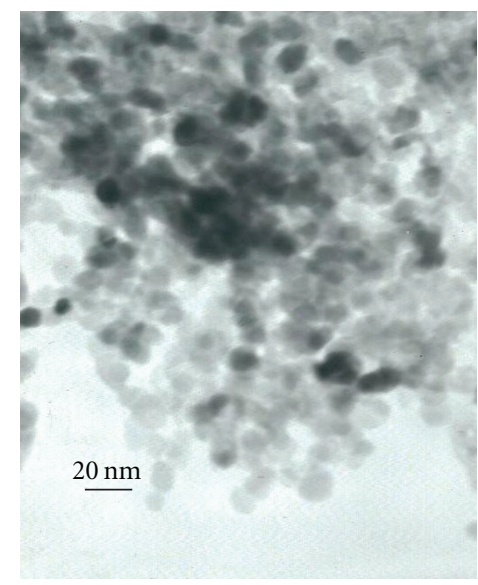

(b)

FIGURE 5: TEM micrographs of (a) sample 125-2 before calcination and (b) the calcinated sample ( $\mathrm{ZnO}$ nanoparticles).

High yield (87-98\%), high purity (96-99\%), and high productivity of $\mathrm{ZnO}$ nanoparticles were obtained (between 1.13 and $1.36 \mathrm{~g} \mathrm{ZnO/100} \mathrm{g} \mathrm{of} \mathrm{reaction} \mathrm{mixture).} \mathrm{This} \mathrm{pro-}$ ductivity is larger than the largest value calculated from the data in the literature, which is $0.73 \mathrm{~g}$ of $\mathrm{ZnO} / 100 \mathrm{~g}$ of microemulsion considering that all $\mathrm{Zn}\left(\mathrm{NO}_{3}\right)_{2}$ is converted to $\mathrm{ZnO}$ [18]; if the total amount of mixture was taken into account (adding the precipitating agent solution), its productivity would be much smaller.

\section{Conclusions}

Here we report the synthesis of $\mathrm{ZnO}$ nanoparticles by hydrolysis and precipitation with $\mathrm{NaOH}$ aqueous solution from bicontinuous microemulsions containing $\mathrm{Zn}\left(\mathrm{NO}_{3}\right)_{2}$ as the precursor, followed by calcination of the precipitate. Primary nanoparticles of $\mathrm{ZnO}$ with average particle size from 6.0 to $22 \mathrm{~nm}$ with high productivity $(1.13$ and $1.36 \mathrm{~g}$ $\mathrm{ZnO} / \mathrm{g}$ of reaction mixture), high yield (87-98\%), and high purity (96-99\%) were obtained. As far as we know, this is the highest productivity of pure $\mathrm{ZnO}$ nanoparticles employing microemulsion media. By increasing the amount of the aqueous $\mathrm{Zn}\left(\mathrm{NO}_{3}\right)_{2}$ solution or decreasing the $\mathrm{NaOH}$ addition rate, smaller particles were produced.

\section{Acknowledgments}

This work was supported by FOMIXJAL (Grant no. 2009-05124211) and CONACYT (Grants nos. CB-2007.82437 and CB-2007.84009). One of us (S. López-Cuenca) acknowledges the scholarship from CONACYT. The authors are grateful to Alejandro Espinoza and Blanca Huerta for their technical assistance.

\section{References}

[1] M. Inoguchi, K. Suzuki, N. Tanaka, K. Kageyama, and H. Takagi, "Structural and optical properties of nanocrystalline $\mathrm{ZnO}$ thin films derived from clear emulsion of monodispersed ZnO nanocrystals," Journal of Materials Research, vol. 24, no. 7, pp. 2243-2251, 2009.

[2] S. Mann, W. Shenton, M. Li, S. Connolly, and D. Fitzmaurice, "Biologically programmed nanoparticle assembly," Advanced Materials, vol. 12, no. 2, pp. 147-150, 2000.

[3] J. C. Johnson, H. Yan, R. D. Schaller, L. H. Haber, R. J. Saykally, and P. Yang, "Single nanowire lasers," Journal of Physical Chemistry B, vol. 105, no. 46, pp. 11387-11390, 2001.

[4] H. Rensmo, K. Keis, H. Lindström et al., "High light-to-energy conversion efficiencies for solar cells based on nanostructured ZnO electrodes," Journal of Physical Chemistry B, vol. 110, no. 45, pp. 2598-2601, 1997.

[5] D.-D. Lee, D.-S. Lee, and K. Pook, "Environmental gas sensors," IEEE Sensors Journal, vol. 1, no. 3, pp. 214-224, 2001.

[6] Q. Li, S. L. Chen, and W. C. Jiang, "Durability of nano $\mathrm{ZnO}$ antibacterial cotton fabric to sweat," Journal of Applied Polymer Science, vol. 103, no. 1, pp. 412-416, 2007.

[7] N. Jones, B. Ray, K. T. Ranjit, and A. C. Manna, "Antibacterial activity of $\mathrm{ZnO}$ nanoparticle suspensions on a broad spectrum of microorganisms," FEMS Microbiology Letters, vol. 279, no. 1, pp. 71-76, 2008.

[8] T. Xu and C. S. Xie, "Tetrapod-like nano-particle $\mathrm{ZnO} /$ acrylic resin composite and its multi-function property," Progress in Organic Coatings, vol. 46, no. 4, pp. 297-301, 2003.

[9] V. Khrenov, M. Klapper, M. Koch, and K. Müllen, "Surface functionalized $\mathrm{ZnO}$ particles designed for the use in transparent nanocomposites," Macromolecular Chemistry and Physics, vol. 206, no. 1, pp. 95-101, 2005.

[10] I. A. Toutorski, T. E. Tkachenko, B. V. Pokidko, N. I. Maliavski, and V. I. Sidorov, "Mechanical properties and structure of zinc-containing latex-silicate composites," Journal of Sol-Gel Science and Technology, vol. 26, no. 1-3, pp. 505-509, 2003.

[11] L. Wang and M. Muhammed, "Synthesis of zinc oxide nanoparticles with controlled morphology," Journal of Materials Chemistry, vol. 9, no. 11, pp. 2871-2878, 1999.

[12] J. E. Rodríguez-Paéz, A. C. Caballero, M. Villegas, C. Moure, P. Durán, and J. F. Fernández, "Controlled precipitation methods: formation mechanism of $\mathrm{ZnO}$ nanoparticles," Journal of the European Ceramic Society, vol. 21, no. 7, pp. 925-930, 2001.

[13] M. Purica, E. Budianu, E. Rusu, M. Danila, and R. Gavrila, "Optical and structural investigation of $\mathrm{ZnO}$ thin films prepared by chemical vapor deposition (CVD)," Thin Solid Films, vol. 403-404, pp. 485-488, 2002.

[14] N. Audebrand, J. P. Auffrédic, and D. Louër, "X-ray diffraction study of the early stages of the growth of nanoscale zinc 
oxide crystallites obtained from thermal decomposition of four precursors. General concepts on precursor-dependent microstructural properties," Chemistry of Materials, vol. 10, no. 9, pp. 2450-2461, 1998.

[15] Y. Yang, H. Chen, B. Zhao, and X. Bao, "Size control of $\mathrm{ZnO}$ nanoparticles via thermal decomposition of zinc acetate coated on organic additives," Journal of Crystal Growth, vol. 263, no. 1-4, pp. 447-453, 2004.

[16] C. H. Lu and C. H. Yeh, "Influence of hydrothermal conditions on the morphology and particle size of zinc oxide powder," Ceramics International, vol. 26, no. 4, pp. 351-357, 2000.

[17] Y. Zhu and Y. Zhou, "Preparation of pure ZnO nanoparticles by a simple solid-state reaction method," Applied Physics A, vol. 92, no. 2, pp. 275-278, 2008.

[18] T. Tani, L. Mädler, and S. E. Pratsinis, "Homogeneous ZnO nanoparticles by flame spray pyrolysis," Journal of Nanoparticle Research, vol. 4, no. 4, pp. 337-343, 2002.

[19] S. Hingorani, V. Pillai, P. Kumar, M. S. Multani, and D. O. Shah, "Microemulsion mediated synthesis of zinc-oxide nanoparticles for varistor studies," Materials Research Bulletin, vol. 28, no. 12, pp. 1303-1310, 1993.

[20] S. Hingorani, D. O. Shah, and M. S. Multani, "Effect of process variables on the grain growth and microstructure of $\mathrm{ZnO}$ $\mathrm{Bi}_{2} \mathrm{O}_{3}$ varistors and their nanosize $\mathrm{ZnO}$ precursors," Journal of Materials Research, vol. 10, no. 2, pp. 461-467, 1995.

[21] M. Singhal, V. Chhabra, P. Kang, and D. O. Shah, "Synthesis of $\mathrm{ZnO}$ nanoparticles for varistor application using $\mathrm{Zn}$ substituted aerosol OT microemulsion," Materials Research Bulletin, vol. 32, no. 2, pp. 239-247, 1997.

[22] B. P. Lim, J. Wang, S. C. Ng, C. H. Chew, and L. M. Gan, "A bicontinuous microemulsion route to zinc oxide powder," Ceramics International, vol. 24, no. 3, pp. 205-209, 1998.

[23] M. Inoguchi, K. Suzuki, K. Kageyama, H. Takagi, and Y. Sakabe, "Monodispersed and well-crystallized zinc oxide nanoparticles fabricated by microemulsion method," Journal of the American Ceramic Society, vol. 91, no. 12, pp. 3850-3855, 2008.

[24] J. B. Nagy, Handbook of Microemulsión Science and Technology, Marcel Dekker, New York, NY, USA, 1999.

[25] K. Osseo-Asare, Handbook of Microemulsión Science and Technology, Marcel Dekker, New York, NY, USA, 1999.

[26] A. G. Roca, R. Costo, A. F. Rebolledo et al., "Progress in the preparation of magnetic nanoparticles for applications in biomedicine," Journal of Physics D, vol. 42, no. 22, Article ID 224002, 11 pages, 2009.

[27] J. Esquivel, I. A. Facundo, M. E. Treviño, and R. G. López, "A novel method to prepare magnetic nanoparticles: precipitation in bicontinuous microemulsions," Journal of Materials Science, vol. 42, no. 21, pp. 9015-9020, 2007.

[28] A. L. Loo, M. G. Pineda, H. Saade, M. E. Treviño, and R. G. López, "Synthesis of magnetic nanoparticles in bicontinuous microemulsions. Effect of surfactant concentration," Journal of Materials Science, vol. 43, no. 10, pp. 3649-3654, 2008.

[29] P. Y. Reyes, J. A. Espinoza, M. E. Treviño, H. Saade, and R. G. López, "Synthesis of silver nanoparticles by precipitation in bicontinuous microemulsions," Journal of Nanomaterials, vol. 2010, Article ID 948941, 7 pages, 2010.

[30] H. F. Eicke, M. Borkovec, and B. Das-Gupta, "Conductivity of water-in-oil microemulsions: a quantitative charge fluctuation model," Journal of Physical Chemistry, vol. 93, no. 1, pp. 314317, 1989.

[31] M. Borkovec, H. F. Eicke, H. Hammerich, and B. D. DasGupta, "Two percolation processes in microemulsions," Journal of Physical Chemistry, vol. 92, no. 1, pp. 206-211, 1988.
[32] J. F. Billman and E. W. Kaler, "Structure and phase behavior in five-component microemulsions," Langmuir, vol. 6, no. 3, pp. 611-620, 1990.

[33] A. Maitra, C. Mathew, and M. Varshney, "Closed and open structure aggregates in microemulsions and mechanism of percolative conduction," Journal of Physical Chemistry, vol. 94, no. 13, pp. 5290-5292, 1990.

[34] M. Gusatti, R. J. de Almeida, C. E Maduro et al., "Production and characterization of $\mathrm{ZnO}$ nanocrystals obtained by solochemical processing at different temperatures," Journal of Nanoscience and Nanotechnology, vol. 10, no. 7, pp. 4348-4351, 2010 . 

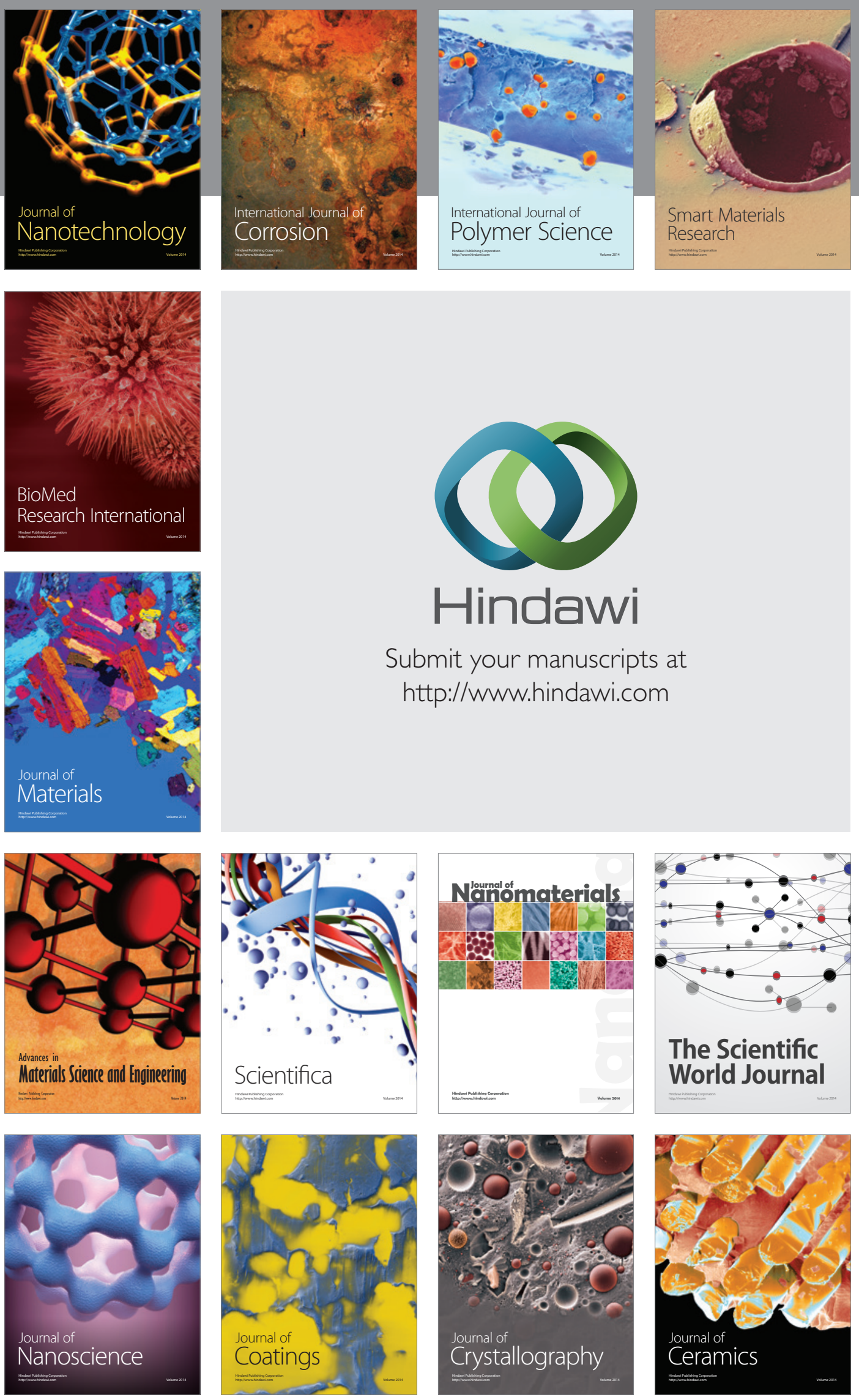

The Scientific World Journal

Submit your manuscripts at

http://www.hindawi.com

\section{World Journal}

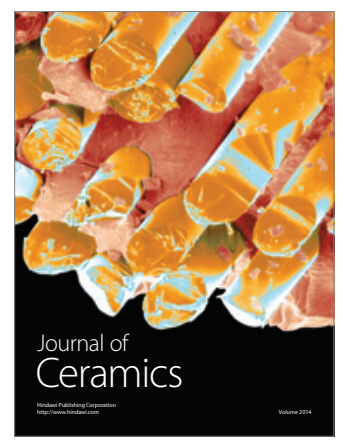

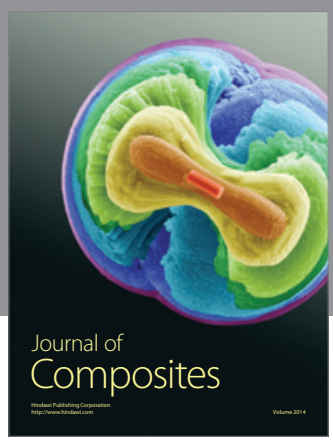
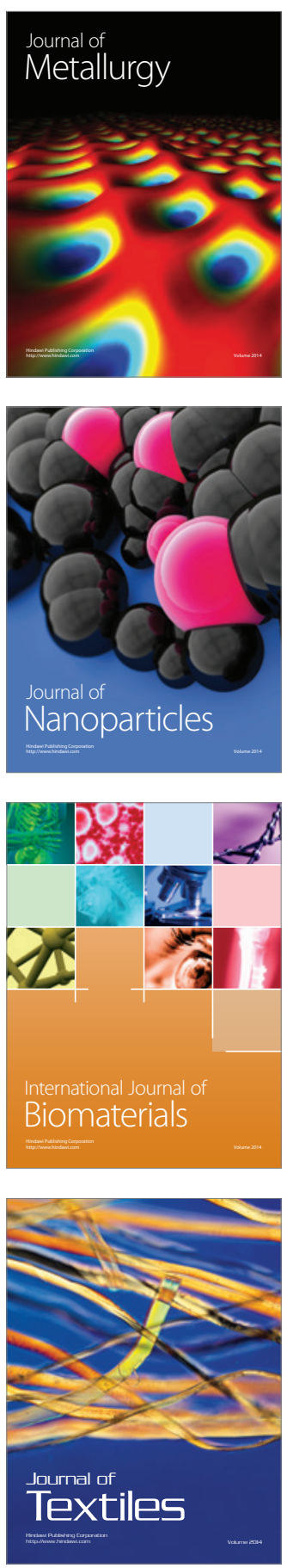